\title{
ANTIOXIDATIVE AND FREE RADICAL SCAVENGING POTENTIALS OF CYCLOSORUS INTERRUPTUS (WILLD.) H. ITÔ AND PRONEPHRIUM NUDATUM (ROXB. EX GRIFF.) HOLTTUM
}

\author{
ABHIJIT MITRA ${ }^{1}$, MANABENDRA DUTTA CHOUDHURY ${ }^{1}$, PRAKASH ROY CHOUDHURY ${ }^{1}$, DEEPA NATH ${ }^{2}$, \\ SUBRATA DAS ${ }^{1}$, ANUPAM DAS TALUKDAR ${ }^{1 *}$
}

\begin{abstract}
${ }^{1}$ Department of Life Science and Bioinformatics, Ethnobotany and Medicinal Plant Research Laboratory, Assam University, Silchar, Assam, India. ${ }^{2}$ Department of Botany and Biotechnology, Karimganj College, Karimganj, Assam, India. Email: anupam@bioinfoaus.ac.in
\end{abstract}

Received: 14 January 2019, Revised and Accepted: 08 May 2019

ABSTRACT

Objectives: The work aims to screen the antioxidative potentials of different crude extracts of the fronds of two medicinally important pteridophytes of Southern Assam, India, namely, Cyclosorus interruptus (Willd.) H. Itô and Pronephrium nudatum (Roxb. ex Griff.) Holttum.

Methods: Frond extracts of the pteridophytes were prepared by Soxhlet hot extraction method. Total phenolic content (TPC) and total flavonoid content (TFC) of the hexane, ethyl acetate, acetone, and methanol extracts of the fronds of the plants were done by following standard protocol. In vitro assessment of the antioxidative behavior of the extracts was performed using standard 2,2-diphenyl-1-picrylhydrazyl scavenging assay, reducing power assay, metal chelating assay, hydroxyl, superoxide, and 2,2'- azino-bis (3-ethylbenzothiazoline - 6 - sulfonic acid) radical scavenging methods in different in vitro systems.

Results: Preliminary phytochemical analysis implicated the presence of phenolic and flavonoid compounds in all the frond extracts. The methanol extract of the fronds of both the plants showed maximum phenolic and flavonoid contents in comparison to the other extracts, however, that of C. interruptus was found to be higher than P. nudatum. Antioxidative potentials of the said extracts were also found to be impressive and noteworthy. The decreasing order of the antioxidative efficacies of the extracts was found to be same as that of TPC and TFC of the extracts.

Conclusion: It is pertinent to comment that the methanol extract of the fronds of both the plants may be treated as a potential source of natural antioxidants.

Keywords: Pteridophytes, Phytochemical, Phenolic, Flavonoid, Antioxidant.

(C) 2019 The Authors. Published by Innovare Academic Sciences Pvt Ltd. This is an open access article under the CC BY license (http://creativecommons. org/licenses/by/4. 0/) DOI: http://dx.doi.org/10.22159/ajpcr.2019.v12i9.32039

\section{INTRODUCTION}

Prolonged persistence of free radicals followed by increasing oxidative stress in the human body triggers the advancement of many diseases including atherosclerosis, hypertension, diabetes mellitus, cancer, multiple sclerosis, liver diseases, kidney diseases, rheumatoid arthritis, aging, neurodegenerative, and cardiovascular disorders [1,2]. Antioxidant activity of plants is supposed to be due to their polyphenolic compounds especially the flavonoids [3], which are known to be potential free radical scavengers, hydrolytic as well as oxidative enzyme inhibitors and active against inflammations [4]. Many published research articles suggest that the bioactivities of these polyphenols correspond to their antioxidative nature [5-7].

Many traditionally used medicinal plants have been validated to possess natural antioxidants [8-12]. Pteridophytes are nonflowering vascular cryptogams including a large group of ignored medicinal plants which are economically significant for their medicinal as well as nutraceutical values. Out of around 12,000 identified pteridophytes from the planet, 1000 species, 70 families, and 191 genera have been documented to exist in India [13,14] and 159 species from Southern Assam, i.e., Barak Valley region of Assam, India [15]. Thelypteridaceae is a family of about 900 pteridophyte species belonging to the order Polypodiales [16] of class Polypodiopsida [17]. Twenty-two species of pteridophytes belonging to Thelypteridaceae family have been reported from this region so far [15].

Cyclosorus interruptus is pantropically distributed and is commonly found in bogs, forested wetlands, uncultivated riverine land areas, and oozing woodland areas. It is also found on floating mats of vegetation in swamps or deep open marshes. Ethnopharmacological reports reflect the traditional use of $C$. interruptus as a remedial source to cure boils, sores, cough, liver diseases, gonorrhea, and malaria [15,18-20]. The boiled fronds of the plant are also used to treat gastric ulcer [18,19], which is apart from being caused by the bacterium, Helicobacter pylori [21] is also assumed to be triggered and aggravated by oxidative stress [22]

Pronephrium nudatum (Roxb. ex Griff.) Holttum of Thelypteridaceae family is a bulky land-dwelling pteridophyte, forming extensive gatherings in the moist forest as vegetation, commonly near rivers. It also grows in damp places in the plane land. The fronds of $P$. nudatum are used to treat pyorrhea and other disorders of teeth gums. A local ethnobotanical report [23] suggests the use of a cold decoction of pinnae of the plant as a mouthwash for 2-3 times/day during acute pyorrhea [15,24,25]. Although the two plants have considerable ethnomedicinal importance, still negligible attempts have been taken to validate their medicinal potentialities. In this article, the in vitro antioxidant as well as free radical scavenging activities of $C$. interruptus and $P$. nudatum frond extracts in various in vitro models have been reported.

\section{MATERIALS AND METHODS}

\section{Collection of plant material}

Fresh fronds of $C$. interruptus (voucher specimen no. 17602) and P. nudatum (voucher specimen no. 46591) were collected from their natural habitats at Dorgakona village of Cachar district and Kamalpur village of Karimganj district of Southern Assam, India respectively. The herbarium sheets of both the collected specimen have been submitted to the Assam University Herbarium and identified from Botanical Survey of India, Shillong. 
Preparation of extracts

Plant material collection was followed by air drying at room temperature for some days. The air-dried fronds of the ferns were powdered using a grinder. From this powder, different crude frond extracts were sequentially prepared by Soxhlet method with various solvents of differential polarity, namely, hexane, ethyl acetate, acetone, and methanol to furnish different frond extracts of less polarity, medium polarity, and high polarity.

\section{Preliminary phytochemical analysis}

Preliminary screening of phytochemicals of the frond extracts was performed following standard phytochemical methods [26].

\section{Estimation of total phenolic content (TPC)}

Total phenolic contents of the frond extracts were estimated by following the Folin-Ciocalteu (FC) method. To $0.1 \mathrm{~mL}$ of the sample, $0.2 \mathrm{~mL} 10 \% \mathrm{v} / \mathrm{v}$ FC reagent was added and was constantly shaken for $5 \mathrm{~min}$, followed by addition of $0.8 \mathrm{~mL}$ of sodium carbonate $\left(\mathrm{Na}_{2} \mathrm{CO}_{3}\right)$. This mixture was then subjected to room temperature-incubation for $2 \mathrm{~h}$ followed by measurement of absorbance at $765 \mathrm{~nm}$ of wavelength. The standard curve was prepared using different concentrations of gallic acid in methanol $(10-100 \mu \mathrm{g} / \mathrm{ml})$ [27]. The concentrations of phenolic compounds were calculated by employing the following equation, obtained from the standard gallic acid graph:

Absorbance $=0.0608$ gallic acid $(\mu g)-0.0081\left(R^{2}=0.9682\right)$

\section{Estimation of total flavonoid content (TFC)}

TFC of the frond extracts were evaluated following Dowd's method [28]. $1 \mathrm{ml}$ of $2 \%$ aluminum trichloride $\left(\mathrm{AlCl}_{3}\right)$ in methanol was added to equal volume of the methanol-dissolved frond extracts $(2000 \mu \mathrm{g})$. Absorbances of the reaction mixtures at $415 \mathrm{~nm}$ were noted after $10 \mathrm{~min}$. $1 \mathrm{~mL}$ frond extract mixed with $1 \mathrm{ml}$ methanol was used as a blank solution. Calculations of flavonoid concentrations in different extracts were performed applying the following equation, which was achieved from the standard quercetin calibration curve:

\section{Absorbance $=0.0355$ quercetin $(\mu \mathrm{g})-0.2396\left(\mathrm{R}^{2}: 0.9886\right)$}

2,2-diphenyl-1-picrylhydrazyl (DPPH) radical scavenging activity Hydrogen bond donating efficiency of the frond extracts was investigated using stable DPPH radicals [29]. Different concentrations of $0.1 \mathrm{ml}$ of the frond extracts in methanol were mixed with $0.004 \%$ methanolic solution of DPPH $(3 \mathrm{ml})$. After $1 / 2 \mathrm{~h}$, the absorbances (517 $\mathrm{nm}$ ) of the solutions were determined. The absorbance of the DPPH solution is inversely proportional to the DPPH radical scavenging activity. The standard antioxidant quercetin $(50 \mu \mathrm{g} / \mathrm{ml})$ was used as a positive control. DPPH radical scavenging activity (\%) was determined according to the formula as under:

DPPH radical scavenging activity $(\%)=\left[\left(\mathrm{A}_{\text {control }}-\mathrm{A}_{\text {sample }}\right) / \mathrm{A}_{\text {control }}\right] \times 100$

Where $\mathrm{A}_{\text {control }}$ corresponds to the absorbance of the control and $\mathrm{A}_{\text {sample }}$ denotes the absorbance of the sample solution.

\section{Reducing power assay}

The reducing power of the prepared plant extracts was evaluated following Oyaizu's method [30]. $2.5 \mathrm{ml}$ of each extract of different concentrations $(0.2-1.0 \mathrm{mg} / \mathrm{ml})$ in methanol was added to $2.5 \mathrm{ml}$ of sodium phosphate buffer (200 mM; pH 6.6), and $2.5 \mathrm{ml}$ of potassium ferricyanide (1\%). The reaction mixture was then kept for incubation at $50^{\circ} \mathrm{C}$ for $20 \mathrm{~min}$ followed by addition of $2.5 \mathrm{ml}$ of $10 \%$ trichloroacetic acid to the mixture and centrifugation at $200 \mathrm{~g}$ for $10 \mathrm{~min} .2 .5 \mathrm{ml}$ of the above layer was added to the same volume of deionized water and $0.5 \mathrm{ml}$ of $0.1 \%$ ferric chloride. The spectrophotometric absorbance of the mixture was recorded at $700 \mathrm{~nm}$. The standard antioxidant ascorbic acid was used as a positive control for this experiment.

\section{Hydroxyl radical scavenging activity}

Hydroxyl radical scavenging effect of the plant extracts was determined following a standard protocol [31]. $1.5 \mathrm{mM} \mathrm{FeSO}_{4}(0.5 \mathrm{~mL})$ was mixed with $6 \mathrm{mM} \mathrm{H}_{2} \mathrm{O}_{2}(0.35 \mathrm{~mL}), 20 \mathrm{mM}$ sodium salicylate $(0.15 \mathrm{~mL})$, and different concentrations $(0.2-1.0 \mathrm{mg} / \mathrm{mL})$ of the sample $\left(1 \mathrm{ml}\right.$ each). Then, the mixture was kept for incubation at $37^{\circ} \mathrm{C}$ for $1 \mathrm{~h}$. The absorbance of the formed hydroxylated salicylate complex was determined spectrophotometrically at $562 \mathrm{~nm}$. Ascorbic acid was tested as a positive control. The calculation of antioxidant activity was performed as per the following formula:

Scavenging effect $(\%)=1-\left(\mathrm{A}_{\text {sample }}-\mathrm{A}_{\text {blank }}\right) / \mathrm{A}_{\text {control }} \times 100$

where $\mathrm{A}_{\text {sample }}$ denotes the absorbance of the test sample or positive control, $\mathrm{A}_{\text {control }}$ corresponds to the absorbance of the solvent control, and $A_{\text {blank }}$ is the absorbance of reagent blank without sodium salicylate.

\section{Superoxide radical scavenging activity}

Superoxide radical scavenging assay was performed by the pyrogallic acid method [32] with slight modification. To $2.5 \mathrm{~mL}$ of $0.1 \mathrm{M}$ PBS buffer ( $\mathrm{pH}$ 8.2), $4 \mathrm{~mL}$ of the sample solution and $2.5 \mathrm{~mL}$ of $6.0 \mathrm{mM}$ pyrogallic acid were added. Then, $0.5 \mathrm{~mL}$ of hydrochloric acid was added to the reaction mixture to cease the reaction. The solution was then kept for incubation at room temperature and followed by taking the absorbance reading at $299 \mathrm{~nm}$. Ascorbic acid was used as a standard superoxide scavenger. All experimentations were carried out in triplicate. The superoxide radical scavenging activity was determined using the following equation:

Scavenging activity $(\%)=A_{0}-\left(A_{s}-A_{c}\right) / A_{0} \times 100$

Where $A_{s}$ means the absorbance of the solution containing pyrogallic acid and test extract; $A_{0}$ is that of pyrogallic acid but with no test extract; and $\mathrm{A}_{\mathrm{c}}$ denotes the absorbance of the solution containing test extract but no pyrogallic acid.

2,2'- azino-bis (3-ethylbenzothiazoline - 6 - sulfonic acid) $\left(\mathrm{ABTS}^{+}\right.$) cation scavenging activity

The spectrophotometric determination of $\mathrm{ABTS}^{+}$radical scavenging potential was performed using standard protocol [33]. $7 \mathrm{mM}$ ABTS was mixed with $2.45 \mathrm{mM}$ potassium persulfate and was kept for $12 \mathrm{~h}$ in darkness at room temperature. This solution was then diluted with phosphate buffer $(0.1 \mathrm{M}, \mathrm{pH} 7.4)$ to achieve an optical density of $0.700 \pm 0.025$ at $734 \mathrm{~nm}$. Then, $\mathrm{ABTS}^{+}$solution ( $1 \mathrm{ml}$ ) was mixed with different concentrations $(8-40 \mu \mathrm{g} / \mathrm{ml}$ ) of extract solution $(3 \mathrm{ml})$ in methanol. After $1 / 2 \mathrm{~h}$, the inhibition (\%) of $\mathrm{ABTS}^{+}$cation by the plant extract was calculated for each concentration. Methanol was used as the blank solution. The $\mathrm{ABTS}^{+}$radical scavenging activities of the extracts were estimated by employing the equation as under:

$\mathrm{ABTS}^{+}$scavenging effect $(\%)=\left[\left(\mathrm{A}_{\text {control }}-\mathrm{A}_{\text {sample }}\right) / \mathrm{A}_{\text {control }}\right] \times 100$

Where $\mathrm{A}_{\text {control }}$ denotes the initial concentration of $\mathrm{ABTS}^{+}$and $\mathrm{A}_{\text {sample }}$ means the absorbance of leftover $\mathrm{ABTS}^{+}$after reaction with the plant extracts.

\section{Chelating effects on ferrous ions}

The chelating activity of the extracts was evaluated according to the established method [34]. Different concentrations $(0.05-0.25 \mathrm{mg} / \mathrm{ml}$ ) of the extracts in methanol ( $2 \mathrm{ml}$ each) were added to $0.05 \mathrm{ml}$ of $2 \mathrm{mM}$ $\mathrm{FeCl}_{2} .0 .02 \mathrm{ml}$ of $5 \mathrm{mM}$ ferrozine was then added to the reaction mixture to start the reaction. After vigorous shaking, the mixture was incubated at room temperature for $10 \mathrm{~min}$, and the absorbance of the solution was taken spectrophotometrically at $562 \mathrm{~nm}$. The calculation of percentage inhibition of ferrozine- $\mathrm{Fe}^{2+}$ complex formation was done using the following formula:

Metal chelating effect $(\%)=\left[\left(\mathrm{A}_{\text {control }}-\mathrm{A}_{\text {sample }}\right) / \mathrm{A}_{\text {control }}\right] \times 100$

Where $\mathrm{A}_{\text {control }}$ denotes the absorbance of control that contains $\mathrm{FeCl}_{2}$ and ferrozine and $\mathrm{A}_{\text {sample }}$ corresponds to the absorbance of the test material. Ethylenediaminetetraacetic acid (EDTA) was used as a standard chelating ligand. 


\section{RESULTS}

\section{Preliminary phytochemical analysis}

The preliminary phytochemical screening results showed the presence of phenols and flavonoids in all the prepared extracts of both the plants. Alkaloids were found to be present in ethyl acetate and methanol extract of $C$. interruptus, whereas it was found only in the ethyl acetate extract of $P$. nudatum. Hexane, ethyl acetate and acetone extracts of both the plants implicated the presence of saponins. Tannins' presence was observed in the hexane and acetone extract of $P$. nudatum, whereas, it was present in the methanol extract of $C$. interruptus only. Acetone extract of $C$. interruptus showed the presence of reducing sugar, whereas it was found in the hexane extract of $P$. nudatum only.

\section{Estimation of TPC and TFC}

The methanolic frond extract of $C$. interruptus was found to possess the highest phenolic $(299.0 \pm 1.1 \mu \mathrm{g}$ gallic acid equivalents [GAEs] $/ \mathrm{mg}$ of extract) as well as flavonoid content $(254.1 \pm 4.1 \mu \mathrm{g}$ quercetin equivalents [QEs]/mg of extract) of all the extracts (Table 1 and Figs. 1-2). However, the methanolic extract of P. nudatum was found to possess the TPC and TFC values of $223.0 \pm 6.80 \mu \mathrm{g}$ GAEs/mg of extract and 188.4 $\pm 5.74 \mu \mathrm{g}$ QEs/mg of extract, respectively. These values were followed by the acetone, ethyl acetate, and hexane extracts of both the plants. The lowest TPC and TFC were manifested by the hexane extract of $P$. nudatum fronds $(61.4 \pm 1.84 \mu \mathrm{g}$ GAEs/mg of extract and $29.2 \pm 1.30 \mu \mathrm{g}$ QEs/mg of extract, respectively).

\section{DPPH radical scavenging activity}

The results of the DPPH free radical scavenging ability of all the extracts are shown in Table 2 and Fig. 3. The positive control, i.e., quercetin was found to possess the highest scavenging activity in all concentrations with an halfmaximal inhibitory concentration $\left(\mathrm{IC}_{50}\right.$ ) value of $0.510 \pm 0.012 \mathrm{mg} / \mathrm{ml}$. As compared to that the methanolic frond extract of $C$. interruptus was found to possess the highest DPPH radical scavenging activities of all the extracts with an $\mathrm{IC}_{50}$ value of $0.760 \pm 0.003 \mathrm{mg} / \mathrm{ml}$ followed by the other extracts of decreasing solvent polarity. However, the methanol extract of $P$. nudatum showed an IC $\mathrm{C}_{50}$ value of $0.980 \pm 0.030 \mathrm{mg} / \mathrm{ml}$.

\section{Reducing power assay}

Table 3 and Fig. 4 illustrate the ferric ion reducing power of all the extracts/standard. The reducing power of all the prepared extracts

Table 1: TPC and TFC of the prepared frond extracts

\begin{tabular}{llll}
\hline $\begin{array}{l}\text { Name of the } \\
\text { plants }\end{array}$ & Extracts & $\begin{array}{l}\text { TPC }(\boldsymbol{\mu g} \text { eq. of gallic acids/mg of extract) } \\
\text { (Mean } \pm \text { SD) }\end{array}$ & $\begin{array}{l}\text { TFC ( } \boldsymbol{\mu g} \text { eq. of quercetin/mg of extract) } \\
\text { (Mean } \pm \text { SD) }\end{array}$ \\
\hline C. interruptus & Hexane & $79.2 \pm 2.3$ & $48.2 \pm 3.1$ \\
& Ethyl acetate & $148.7 \pm 1.1$ & $78.1 \pm 2.2$ \\
& Acetone & $196.1 \pm 2.7$ & $152.9 \pm 3.1$ \\
& Methanol & $299.0 \pm 1.1$ & $254.1 \pm 4.1$ \\
P. nudatum & Hexane & $61.4 \pm 1.3$ & $29.2 \pm 1.3$ \\
& Ethyl acetate & $121.6 \pm 1.7$ & $34.5 \pm 1.1$ \\
& Acetone & $167.4 \pm 3.5$ & $106.2 \pm 0.7$ \\
& Methanol & $223.0 \pm 2.8$ & $188.4 \pm 4.0$ \\
\hline
\end{tabular}

TFC: Total Flavonoid Content, C. interruptus=Cyclosorus interruptus, $P$. nudatum: Pronephrium nudatum, TPC=Total Phenolic Content, SD=Standard deviation

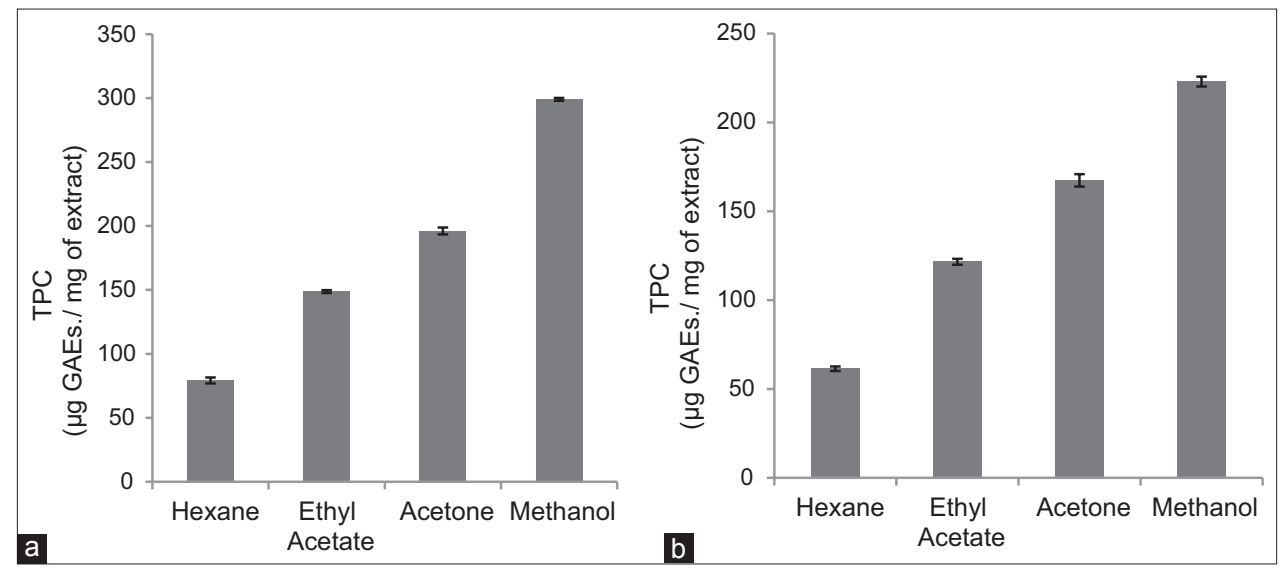

Fig. 1: (a and b) Total phenolic content of different frond extracts of (a) Cyclosorus interruptus and (b) Pronephrium nudatum
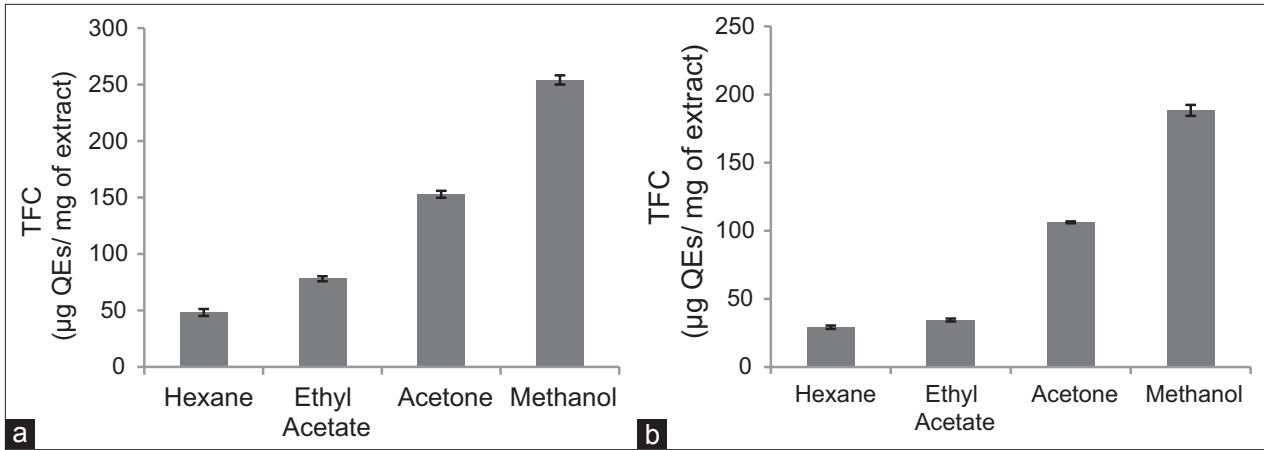

Fig. 2: (a and b) Total flavonoid content of different frond extracts of (a) Cyclosorus interruptus and (b) Pronephrium nudatum 
Table 2: DPPH free radical scavenging activities of the plant extracts

\begin{tabular}{|c|c|c|}
\hline Extracts/standard & $\mathrm{IC}_{50}$ values of $C$. interruptus $(\mathrm{mg} / \mathrm{ml})($ Mean $\pm \mathrm{SD})$ & $\mathrm{IC}_{50}$ values of $P$. nudatum $(\mathrm{mg} / \mathrm{ml})($ Mean $\pm \mathrm{SD})$ \\
\hline Hexane & $1.460 \pm 0.010$ & $1.910 \pm 0.007$ \\
\hline Ethyl acetate & $1.110 \pm 0.005$ & $1.840 \pm 0.011$ \\
\hline Acetone & $0.860 \pm 0.021$ & $1.360 \pm 0.004$ \\
\hline Methanol & $0.760 \pm 0.003$ & $0.980 \pm 0.030$ \\
\hline Quercetin & $0.510 \pm 0.012$ & $0.510 \pm 0.012$ \\
\hline
\end{tabular}

DPPH=2.2-diphenyl-1-picrylhydrazyl, SD=Standard deviation, C. interruptus=Cyclosorus interruptus, P. nudatum: Pronephrium nudatum, IC ${ }_{50}$ : Half-maximal inhibitory concentration

Table 3: Reducing power assay of the frond extract

\begin{tabular}{|c|c|c|c|c|c|c|}
\hline \multirow[t]{2}{*}{ Name of the plants } & \multirow[t]{2}{*}{ Extracts/standard } & \multicolumn{5}{|c|}{ Absorbance at $700 \mathrm{~nm}(\mathrm{mg} / \mathrm{ml})($ Mean \pm SD $)$} \\
\hline & & 0.2 & 0.4 & 0.6 & 0.8 & 1.0 \\
\hline \multirow[t]{3}{*}{ C. interruptus } & Hexane & $0.098 \pm 0.007$ & $0.142 \pm 0.009$ & $0.178 \pm 0.010$ & $0.252 \pm 0.004$ & $0.398 \pm 0.005$ \\
\hline & Acetone & $0.636 \pm 0.008$ & $0.686 \pm 0.002$ & $0.779 \pm 0.009$ & $0.825 \pm 0.004$ & $0.888 \pm 0.003$ \\
\hline & Methanol & $0.701 \pm 0.012$ & $0.771 \pm 0.009$ & $0.790 \pm 0.008$ & $0.799 \pm 0.002$ & $0.921 \pm 0.007$ \\
\hline \multirow[t]{5}{*}{ P. nudatum } & Hexane & $0.042 \pm 0.001$ & $0.137 \pm 0.004$ & $0.152 \pm 0.002$ & $0.199 \pm 0.011$ & $0.234 \pm 0.009$ \\
\hline & Ethyl acetate & $0.089 \pm 0.002$ & $0.152 \pm 0.005$ & $0.203 \pm 0.010$ & $0.256 \pm 0.012$ & $0.316 \pm 0.003$ \\
\hline & Acetone & $0.182 \pm 0.007$ & $0.287 \pm 0.004$ & $0.355 \pm 0.013$ & $0.381 \pm 0.006$ & $0.495 \pm 0.021$ \\
\hline & Methanol & $0.333 \pm 0.007$ & $0.392 \pm 0.003$ & $0.477 \pm 0.019$ & $0.599 \pm 0.022$ & $0.678 \pm 0.003$ \\
\hline & Ascorbic acid & $0.215 \pm 0.004$ & $0.298 \pm 0.008$ & $0.387 \pm 0.002$ & $0.452 \pm 0.015$ & $0.561 \pm 0.003$ \\
\hline
\end{tabular}

C. interruptus=Cyclosorus interruptus, $P$. nudatum: Pronephrium nudatum, $\mathrm{SD}=$ Standard deviation
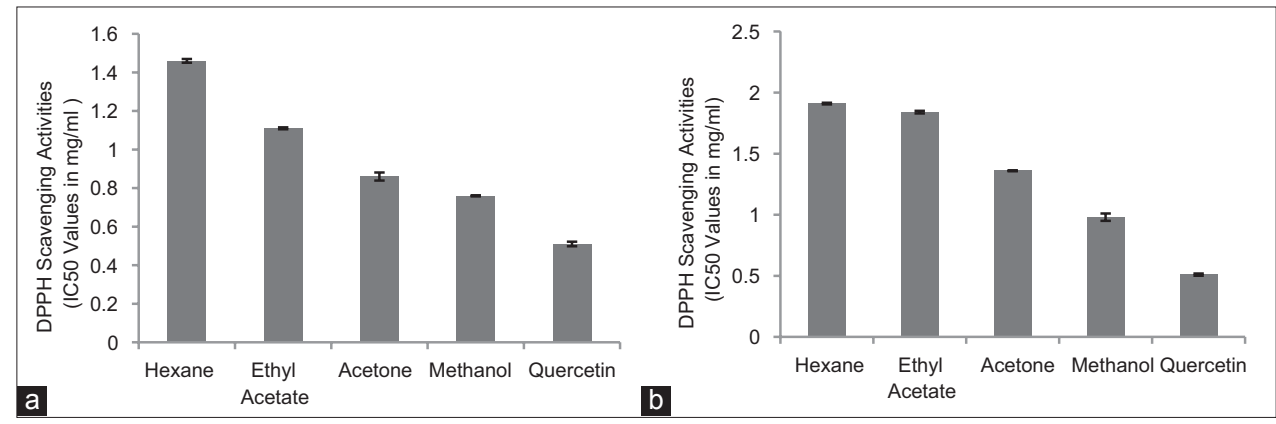

Fig. 3: (a and b) 2.2-diphenyl-1-picrylhydrazyl radical scavenging activities of different extracts of (a) Cyclosorus interruptus and (b) Pronephrium nudatum

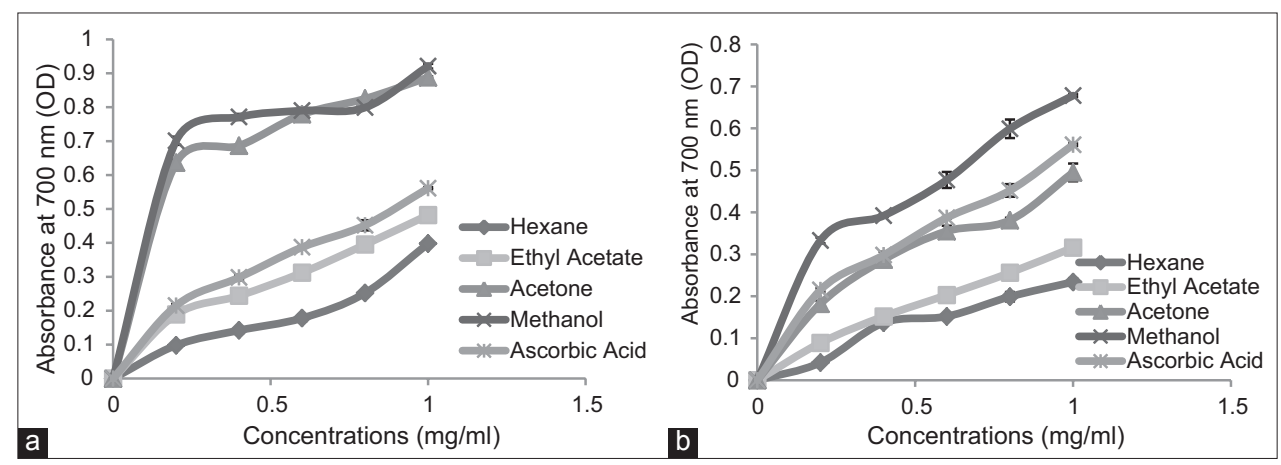

Fig. 4: Reducing power of the different extracts of (a) Cyclosorus interruptus and (b) Pronephrium nudatum

increased with increase in concentration. At $1.0 \mathrm{mg} / \mathrm{ml}$ concentration, the reducing potential of acetone $(0.888 \pm 0.003)$ and methanol extract $(0.921 \pm 0.007)$ of $C$. interruptus was found to be higher than the ascorbic acid control $(0.561 \pm 0.003)$. However, the methanol extract of $P$. nudatum fronds was also found to possess higher reducing power with an absorbance value of $0.678 \pm 0.003$ than the standard compound.

Hydroxyl radical scavenging activity

The hydroxyl radical scavenging activity of all the extracts is shown in Table 4 and Fig. 5. The ascorbic acid standard was found to exhibit the highest hydroxyl radical scavenging activity with an $\mathrm{IC}_{50}$ value of $0.290 \pm 0.007 \mathrm{mg} / \mathrm{ml}$ followed by the methanol extract of $C$. interruptus having an $\mathrm{IC}_{50}$ value of $0.330 \pm 0.005 \mathrm{mg} / \mathrm{ml}$ and methanol extract of $P$. nudatum having an $\mathrm{IC}_{50}$ value of $0.490 \pm 0.005 \mathrm{mg} / \mathrm{ml}$. It was found to be the lowest in the hexane extract of $P$. nudatum.

Superoxide radical scavenging activity

The superoxide radical scavenging activity of the plant extracts/ standard is shown in Table 5 and Fig. 6 . The methanolic frond extract of $C$. interruptus revealed the highest superoxide radical scavenging 
activity with an $\mathrm{IC}_{50}$ value of $0.260 \pm 0.006 \mathrm{mg} / \mathrm{ml}$ which was slightly less than that of the ascorbic acid standard having an $\mathrm{IC}_{50}$ value of $0.230 \pm 0.006 \mathrm{mg} / \mathrm{ml}$. The methanolic frond extract of $P$. nudatum was found to possess good activity against superoxide radicals with an IC $_{50}$ value of $0.690 \pm 0.009 \mathrm{mg} / \mathrm{ml}$. However, it was much less than that of C. interruptus.

\section{ABTS $^{+}$cation scavenging activity}

Table 6 and Fig. 7 illustrate the $\mathrm{ABTS}^{+}$cation scavenging activity of the plant extracts. As a result of this assay, the highest activity was observed in the methanolic extract of $C$. interruptus $(67.42 \pm 2.09 \%)$ at the concentration of $40 \mu \mathrm{g} / \mathrm{ml}$ followed by the other extracts of decreasing solvent polarity. The percentage scavenging effect of the methanolic frond extract of P. nudatum was found to be $51.18 \pm 2.16 \%$ at the same concentration of the extract.
Chelating effect on ferrous ions

The percentage metal-chelating effect (Table 7 and Fig. 8) of the standard chelating ligand, i.e., EDTA was found to be the highest (97.24 $\pm 5.6 \%)$ at the concentration of $0.250 \mathrm{mg} / \mathrm{ml}$ followed by the methanol extract of $C$. interruptus fronds $(94.27 \pm 2.7 \%)$ which was much higher than that of methanolic frond extract of $P$. nudatum $(69.14 \pm 4.1 \%)$. The metal-chelating effect of the extracts was also found to be decreasing concerning the decreasing solvent polarity.

\section{Statistical analysis}

All the data have been reported as the mean \pm standard deviation of triplicate measurements. Calculation of mean, SD, and preparation of graphs was made in Microsoft Excel-2013. ANOVA was performed by using SPSS software for Windows, Version 16.0. $\mathrm{p}<0.05$ was regarded as significant.

Table 4: $\mathrm{IC}_{50}$ values of the plant extracts for eliminating hydroxyl radicals

\begin{tabular}{lll}
\hline Extracts/standard & IC $_{\mathbf{5 0}}$ values of $\boldsymbol{C}$. interruptus $\mathbf{( m g / m l )}(\mathbf{M e a n} \pm \mathbf{S D})$ & IC $_{\mathbf{5 0}}$ values of $\boldsymbol{P}$. $\mathbf{n u d a t u m}$ (mg/ml) $\left.\mathbf{( M e a n} \pm \mathbf{S D}\right)$ \\
\hline Hexane & $0.980 \pm 0.018$ & $1.410 \pm 0.021$ \\
Ethyl acetate & $0.470 \pm 0.004$ & $0.980 \pm 0.005$ \\
Acetone & $0.380 \pm 0.009$ & $0.740 \pm 0.007$ \\
Methanol & $0.330 \pm 0.005$ & $0.490 \pm 0.001$ \\
Ascorbic acid & $0.290 \pm 0.007$ & $0.290 \pm 0.007$ \\
\hline
\end{tabular}

C. interruptus=Cyclosorus interruptus, P. nudatum: Pronephrium nudatum, $\mathrm{SD}=$ Standard deviation, $\mathrm{IC}_{50}$ : Half-maximal inhibitory concentration

Table 5: $\mathrm{IC}_{50}$ values of the plant extracts for eliminating superoxide radicals

\begin{tabular}{lll}
\hline Extracts/standard & IC $_{\mathbf{5 0}}$ values of $\boldsymbol{C}$. interruptus $\mathbf{( m g / m l )}(\mathbf{M e a n} \pm \mathbf{S D})$ & IC $_{\mathbf{5 0}}$ values of $\boldsymbol{P}$. $\mathbf{n u d a t u m}$ (mg/ml) $(\mathbf{M e a n} \pm \mathbf{S D})$ \\
\hline Hexane & $0.860 \pm 0.006$ & $1.500 \pm 0.003$ \\
Ethyl acetate & $0.590 \pm 0.011$ & $1.110 \pm 0.001$ \\
Acetone & $0.350 \pm 0.004$ & $0.920 \pm 0.002$ \\
Methanol & $0.260 \pm 0.005$ & $0.690 \pm 0.006$ \\
Ascorbic acid & $0.230 \pm 0.006$ & $0.230 \pm 0.006$ \\
\hline
\end{tabular}

C. interruptus=Cyclosorus interruptus, $P$. nudatum: Pronephrium nudatum, $\mathrm{SD}=$ Standard deviation, $\mathrm{IC}_{50}$ : Half-maximal inhibitory concentration
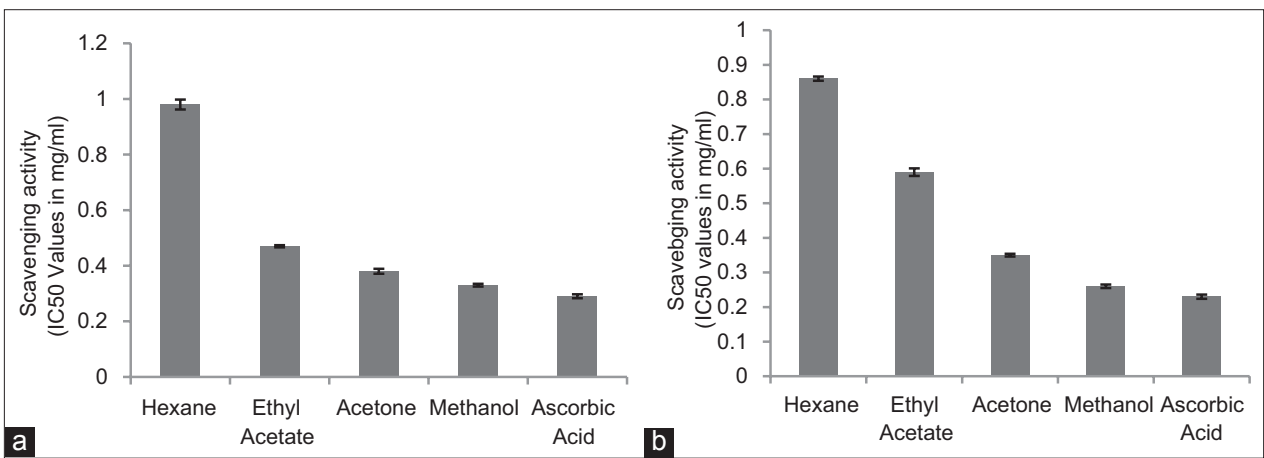

Fig. 5: (a and b) Hydroxyl radical scavenging activities of different extracts of (a) Cyclosorus interruptus and (b) Pronephrium nudatum

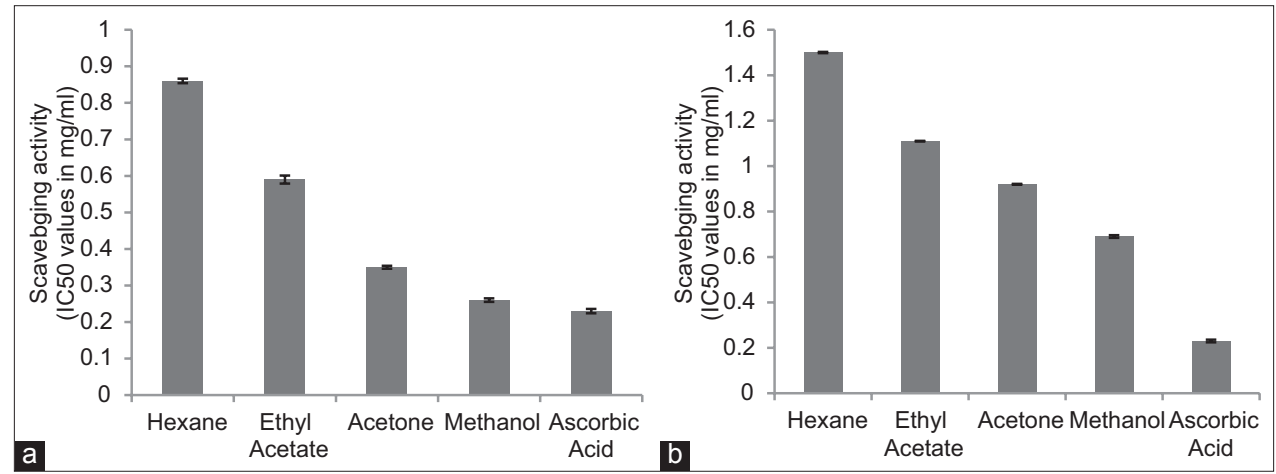

Fig. 6: (a and b) Superoxide radical scavenging activities of different extracts of (a) Cyclosorus interruptus and (b) Pronephrium nudatum 
Table 6: Scavenging (\%) effect of the extracts on the stable ABTS'radical

\begin{tabular}{|c|c|c|c|c|}
\hline \multirow[t]{2}{*}{ Name of the plants } & \multirow[t]{2}{*}{ Extracts/standard } & \multicolumn{3}{|c|}{$\%$ Scavenging effect $($ Mean \pm SD) $(\mu \mathrm{g} / \mathrm{ml})$} \\
\hline & & 8 & 20 & 40 \\
\hline \multirow[t]{4}{*}{ C. interruptus } & Hexane & $19.58 \pm 2.26$ & $28.63 \pm 1.52$ & $35.69 \pm 1.18$ \\
\hline & Ethyl acetate & $31.89 \pm 0.079$ & $41.95 \pm 2.16$ & $52.63 \pm 1.32$ \\
\hline & Acetone & $36.91 \pm 0.08$ & $49.38 \pm 1.56$ & $57.26 \pm 2.76$ \\
\hline & Methanol & $43.21 \pm 1.14$ & $56.91 \pm 2.12$ & $67.42 \pm 2.09$ \\
\hline \multirow[t]{4}{*}{ P. nudatum } & Hexane & $4.81 \pm 0.076$ & $10.09 \pm 1.01$ & $22.21 \pm 1.77$ \\
\hline & Ethyl acetate & $12.67 \pm 0.12$ & $26.09 \pm 1.19$ & $31.87 \pm 2.10$ \\
\hline & Acetone & $19.44 \pm 1.01$ & $29.43 \pm 2.01$ & $37.86 \pm 1.22$ \\
\hline & Methanol & $26.51 \pm 1.09$ & $38.77 \pm 1.91$ & $51.18 \pm 2.16$ \\
\hline
\end{tabular}

C. interruptus=Cyclosorus interruptus, $P$. nudatum: Pronephrium nudatum, $\mathrm{SD}=$ Standard deviation, $\mathrm{IC}_{50}$ : Half-maximal inhibitory concentration

Table 7: Metal chelating effect of the extracts on $\mathrm{Fe}^{2+}$ ions

\begin{tabular}{|c|c|c|c|c|}
\hline \multirow[t]{2}{*}{ Name of the plants } & \multirow[t]{2}{*}{ Extracts/standard } & \multicolumn{3}{|c|}{$\%$ chelating effect (Mean \pm SD) } \\
\hline & & $0.050 \mathrm{mg} / \mathrm{ml}$ & $0.150 \mathrm{mg} / \mathrm{ml}$ & $0.250 \mathrm{mg} / \mathrm{ml}$ \\
\hline \multirow[t]{4}{*}{ C. interruptus } & Hexane & $19.26+2.6$ & $26.84 \pm 1.3$ & $33.48 \pm 2.1$ \\
\hline & Ethyl acetate & $34.08 \pm 1.9$ & $46.07 \pm 4.6$ & $52.23 \pm 3.1$ \\
\hline & Acetone & $71.17 \pm 5.2$ & $79.39 \pm 2.9$ & $84.27 \pm 2.0$ \\
\hline & Methanol & $81.42 \pm 2.1$ & $90.00 \pm 1.4$ & $94.27 \pm 2.7$ \\
\hline \multirow[t]{5}{*}{ P. nudatum } & Hexane & $06.41 \pm 0.7$ & $16.65 \pm 2.0$ & $19.89 \pm 1.4$ \\
\hline & Ethyl acetate & $11.91 \pm 0.9$ & $29.88 \pm 1.2$ & $39.67 \pm 2.2$ \\
\hline & Acetone & $39.11 \pm 3.7$ & $47.10 \pm 4.2$ & $61.77 \pm 2.9$ \\
\hline & Methanol & $51.99 \pm 1.3$ & $64.43 \pm 3.9$ & $69.14 \pm 4.1$ \\
\hline & EDTA & $89.29 \pm 3.6$ & $92.83 \pm 2.40$ & $97.24 \pm 5.6$ \\
\hline
\end{tabular}

C. interruptus=Cyclosorus interruptus, $P$. nudatum: Pronephrium nudatum, $\mathrm{SD}=$ Standard deviation
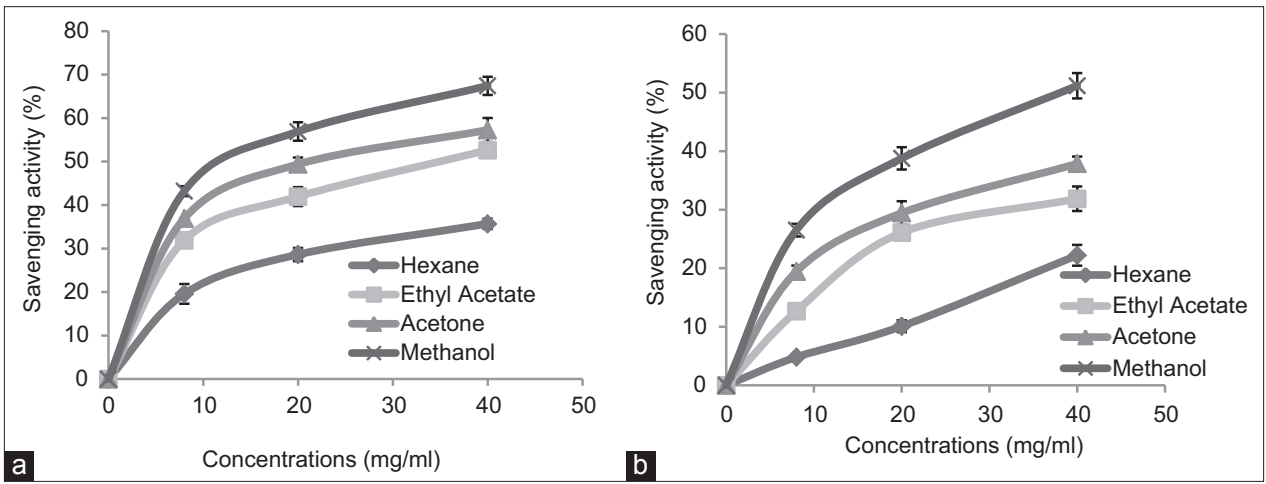

Fig. 7: (a and b) 2,2'- azino-bis (3-ethylbenzothiazoline - 6 - sulfonic acid) ${ }^{+}$cation scavenging activity (\%) of various frond extracts of (a) Cyclosorus interruptus and (b) Pronephrium nudatum
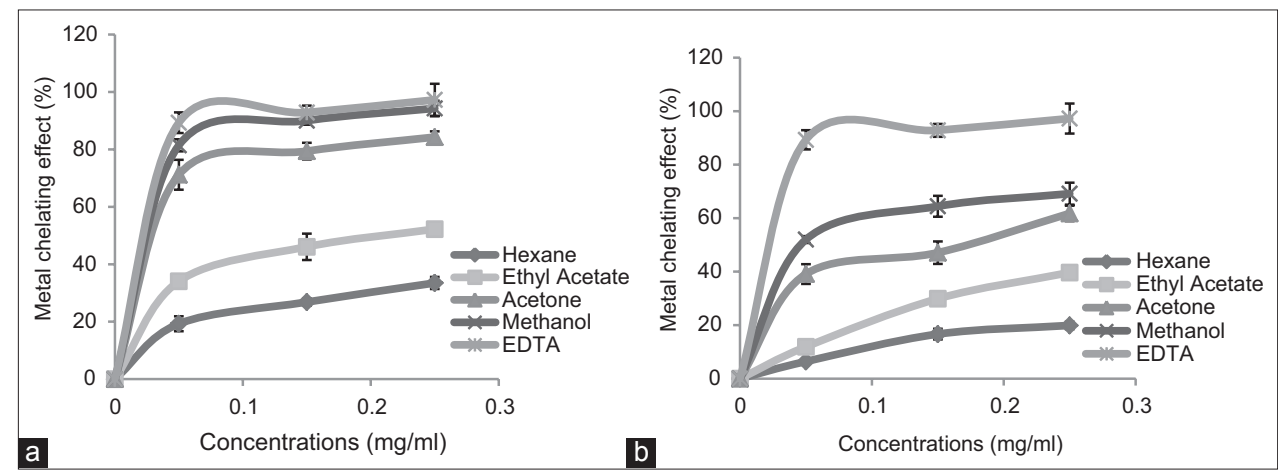

Fig. 8: (a and b) Metal chelating effect of different frond extracts of (a) Cyclosorus interruptus and (b) Pronephrium nudatum

\section{DISCUSSION}

A detailed study on the earlier published literature indicates the traditional medicinal uses of $C$. interruptus and $P$. nudatum (Thelypteridaceae) by different tribes of people for the treatment of various oxidative stress associated diseases and disorders $[15,18,19,22-24]$ and hence it can be inferred that the selected ferns should possess potent antioxidant activities. The validated antimicrobial potentials of pteridophytes also correspond to the traditional utilization of ferns as folk medicine against various 
microbial infections [35-38]. The presence of phenolics, flavonoids, and the alkaloids is attributed to exhibit the antioxidant and hepatoprotective activity.

Since the preliminary phytochemical screening results suggest the presence of phenolic and flavonoid compounds in all the prepared frond extracts ofboth the selected plants; hence, the TPCand TFC werequantified for all the extracts of both plants. Literature suggests the important role of polyphenolic compounds in stabilizing lipid peroxidation as well as possessing diverse antioxidative properties $[39,40]$. The phenolic compounds are known to possess direct antioxidative action against the free radicals [8]. Polyphenolic compounds are known to inhibit the progress of mutagenesis and carcinogenesis in humans [41]. As the TPC and TFC of the plant extracts are supposed to be directly proportional to the antioxidative potentials of the extracts [3,4]; hence, all the extracts showed more or less antioxidant activities with respect to their TPC and TFC (Table 1 and Figs. 1-2).

The DPPH radical scavenging activity assay is one of the most convenient methods to investigate the ability of the phenolic components in extracts to perform the activity as hydrogen atom or electron donors [29]. Based on the hydrogen donating potential of the stable DPPH radical, the free radical scavenging capability of the plant extracts was tested [29]. As the methanolic frond extracts of both the plants revealed the highest DPPH scavenging activities (Table 2 and Fig. 3) of all other low polar solvent extracts; hence, it can be inferred that the most potent DPPH radical scavenging compounds in both the two plants are of high polarity. This activity has been found to be relevant with the TPC and TFC of both the plant extracts. Similar findings have been reported in some published research articles [42-44].

The reducing potential of the plant extracts was analyzed by reduction of $\mathrm{Fe}^{3+}$ ions to $\mathrm{Fe}^{2+}$ form in the presence of reducing antioxidants in the plant extracts. The $\mathrm{Fe}^{2+}$ ions were then explored spectrophotometrically by measuring the optical density of developed Perl's Prussian Blue color at $700 \mathrm{~nm}$ of wavelength [30] (Table 3 and Fig. 4). The standard antioxidant, i.e., ascorbic acid was used as a positive control for this experiment. The methanolic frond extract of $C$. interruptus was found to possess the maximum reducing potential in comparison to the other extracts as well as ascorbic acid. The reducing activities of all the extracts have also been found to increase with the increase in the extract concentrations. Similar results have been described in some published literature $[45,46]$.

Hydroxyl is a very reactive free radical which can react with almost all biological macromolecules and is also supposed to be a highly potent contributor of oxidative stress-mediated tissue injuries $[39,47,48]$. Hydroxyl radical scavenging assay was performed as per standard protocol [31]. As shown in Table 4 and Fig. 5, the methanolic extract of C.interruptus fronds possesses the highest scavenging activity against the hydroxyl free radical $\left(\mathrm{IC}_{50}=0.330 \pm 0.005 \mathrm{mg} / \mathrm{ml}\right)$ which was slightly less than the ascorbic acid standard $(0.290 \pm 0.007 \mathrm{mg} / \mathrm{ml})$. In this case, also the methanol extract of $P$. nudatum fronds $\left(\mathrm{IC}_{50}=0.490 \pm 0.005 \mathrm{mg} / \mathrm{ml}\right.$ ) was found to possess less scavenging activity than that of $C$. interruptus. However, the scavenging activity of both the plants decreased along with the polarity of other solvent extracts.

Superoxide is a highly harmful free radical and can be produced by various photochemical reactions. These radicals may undergo decomposition reactions to generate singlet oxygen and hydroxyl radicals as a result of which oxidative stress associated cellular damage, lipid peroxidation, and diseases such as arthritis and Alzheimer's disease may get triggered [49]. The pyrogallic acid method was used to create superoxide radicals [32]. The superoxide scavenging activity of ascorbic acid standard was found to be the highest $\left(\mathrm{IC}_{50}=0.230 \pm 0.006 \mathrm{mg} / \mathrm{ml}\right)$ followed by the methanolic extract of $C$. interruptus $\left(\mathrm{IC}_{50}=0.260 \pm 0.006 \mathrm{mg} / \mathrm{ml}\right.$ ) (Table 5 and Fig. 6). The methanolic frond extract of $P$. nudatum possessed a good but less scavenging activity than $C$. interruptus. $\left(\mathrm{IC}_{50}=0.690 \pm 0.009 \mathrm{mg} / \mathrm{ml}\right)$.
The method to study the $\mathrm{ABTS}^{+}$radical scavenging activities of the plant extracts by decolorization assay [33] is a consistent and prompt method to determine the total antioxidative potential for hydrophilic as well as lipophilic antioxidants/systems [50]. The spectrophotometric analysis of $\mathrm{ABTS}^{+}$radical (Table 6 and Fig. 7) reveals that at the concentration of $40 \mu \mathrm{g} / \mathrm{ml}$ the methanolic extract of $C$. interruptus possesses the most potent $\mathrm{ABTS}^{+}$radical scavenging activity $(67.42 \pm 2.09 \%)$ of all other extracts. The result shown by that of $P$. nudatum at the same concentration was also noteworthy $(51.18 \pm 2.16 \%)$.

The metal chelating effect (Table 7 and Fig. 8) was determined according to the method of Dinis et al. [34]. Lipid peroxidation can be triggered by iron by Fenton reaction, thereby boosting up peroxidation by the degradation of lipid hydroperoxides and formation of peroxyl and alkoxyl radicals that can continue lipid peroxidation reaction by abstracting hydrogen [1]. The percentage metal $\left(\mathrm{Fe}^{2+}\right)$ chelating effect was also found to be the highest in case of methanolic frond extract of C. interruptus $(94.27 \pm 2.7 \%)$ as compared to the other extracts as well as that of $P$. nudatum. However, the highest activity of $C$. interruptus was a bit less than that of EDTA standard $(97.24 \pm 5.6 \%)$ at the concentration of $0.250 \mathrm{mg} / \mathrm{ml}$. Some published articles also describe similar findings $[6,7,45,51]$.

\section{CONCLUSION}

It can be assumed that the methanol extract of the fronds of both the plants, i.e., $C$. interruptus and P. nudatum possess potent free radical scavenging as well as antioxidative capabilities in comparison to the standards and other extracts. However, the overall antioxidant activities of $C$. interruptus frond extracts were found to be much higher than that of P. nudatum.

\section{ACKNOWLEDGMENT}

The authors acknowledge University Grants Commission, Government of India, for providing financial assistance as Major Research Project (sanction letter no. F.41-390/2012/(SR) Dated 01/07/2012) in the Department of Life Science and Bioinformatics, Assam University, Silchar -788 011. The authors also acknowledge the Department of Biotechnology, Government of India, for providing instrumental facility in the form of Institutional Biotech Hub (sanction letter no. BT/04/ NE/2009 Dated 21/09/2010) and free access of Delcon's e-Journal library along with Bioinformatics Infrastructure Facility (sanction letter no. BT/BI/12/042/2007 Dated 11/02/2008) in Assam University, Silchar-788 011

\section{AUTHORS' CONTRIBUTIONS}

Abhijit Mitra performed the experiments and prepared the research article. Prakash Roy Choudhury and Subrata Das helped in the calculation and statistical analysis of the data. Deepa Nath assisted in the collection of medicinal plants and their identification. Manabendra Dutta Choudhury and Anupam Das Talukdar directed the whole work and helped in the preparation of the manuscript.

\section{CONFLICTS OF INTEREST}

There are no conflicts of interest.

\section{REFERENCES}

1. Halliwell B. Antioxidants in human health and disease. Annu Rev Nutr 1996;16:33-50.

2. Lai HY, Lim YY. Evaluation of antioxidant activities of the methanolic extracts of selected ferns in Malaysia. Int J Environ Sci Dev 2001;2:442-7

3. Cook NC, Samman S. Flavonoids- chemistry, metabolism, cardioprotective effects and dietary sources. Nutr Biochem 1996;7:66-76.

4. Frankel E. Nutritional Benefits of Flavonoids. International Conference on Food Factors: Chemistry and Cancer Prevention. Vol. C6. Japan: Hamamatsu; 1995. p. 2. 
5. Gryglewski RJ, Korbut R, Robak J, Swies J. On the mechanism of antithrombotic action of flavonoids. Biochem Pharmacol 1987;36:317-22.

6. Sujatha S, Sekar T. Free-radical scavenging activity leaf extract of Litsea laevigata Gamble. Int J Pharm Pharm Sci 2019;11:96-103.

7. Gashti AB, Prakash HS. Characterization of antioxidant and antiproliferative activities of Indian salmon (Eleutheronema tetradactylum) protein hydrolysates. Int J Pharm Pharm Sci 2016;8:102-8.

8. Duh PD. Antioxidant activity of Burdock (Arctium lappa Linne): Its scavenging effect on free radical and active oxygen. J Am Oil Chem Soc 1998;75:455-61.

9. Hutadilok-Towatana N, Chaiyamutti P, Panthong K, Mahabusarakam W, Rukachaisirikul V. Antioxidant and free radical scavenging activities of some plants used in Thai folk medicine. Pharm Biol 2006;44:221-8.

10. Juntachote $T$, Berghofer E. Antioxidative properties and stability of ethanolic extracts of holy basil and galangal. Food Chem 2005;92:193-202.

11. Lim YY, Lim TT, Tee JJ. Antioxidant properties of several tropical fruits: A comparative study. Food Chem 2007;103:1003-8.

12. Sultana B, Anwar F, Pirzybyiski R. Antioxidant activity of phenolic components present in barks of Azadirachta indica, Terminalia arjuna, Acacia nilotica and Eugenia jambolana Lam. trees. Food Chem 2007; 104:1106-14.

13. Dixit RD, Bhatt GK. Ferns a much neglected group of medicinal plants II. J Res Indian Med 1975;10:68-76.

14. Talukdar AD, Tarafdar RG, Choudhury MD, Nath D, Choudhury S. A review on pteridophyte antioxidants and their potential role in discovery of new drugs. AUJST Biol Environ Sci 2011;7:151-5.

15. Dey P, Sen A, Bhattacharya MK, Pasha MK. A review of the ferns of Barak Valley, Assam, India. J Taxon Biodiv Res 2011;5:33-42.

16. Christenhusz MJ, Zhang XC, Schneider H. A linear sequence of extant families and genera of lycophytes and ferns. Phytotaxa 2011;19:7-54.

17. Smith AR, Pryer KM, Schuettpelz E, Korall P, Schneider H, Wolf PG. A classification for extant ferns. Taxon 2006;55:705-31.

18. Powell JM. Part III. Ethnobotanyin. In: Paijmans K, editor. New Guinea Vegetation. Sec. 3.1. Canberra: CSIRO; 1976a. p. 44-53, 106-83.

19. Powell JM. Some useful wild and domesticated plants of the huli of Papua. Sci N G 1976b;4:173-201.

20. Oyen LP. In: Brink M, Achigan-Dako EG, editors. Prota 16: Fibres/ Plantes fibres. Wageningen, Netherlands: PROTA; 2006.

21. Labenz J, Börsch G. Role of helicobacter pylori eradication in the prevention of peptic ulcer bleeding relapse. Digestion 1994;55:19-23.

22. Tandon R, Khanna HD, Dorababu M, Goel RK. Oxidative stress and antioxidants status in peptic ulcer and gastric carcinoma. Indian $\mathrm{J}$ Physiol Pharmacol 2004;48:115-8.

23. Shil S, Choudhury MD. Ethnomedicinal importance of pteridophytes used by reang tribe of Tripura, North East India. Ethnobotanical Leafl 2009; 13:634-43.

24. Bharti M, Pravesh R. Diversity, distribution and conservation priorities for pteridophytic flora of Ranchi and Latehar district of Jharkhand, India. Int Q J Life Sc 2010;1:123-33.

25. Sen A, Ghosh PD. A note on the ethnobotanical studies of some pteridophytes in Assam. Indian J Tradit Knowl 2011;10:292-5.

26. Siddiqui AA, Ali M. Practical Pharmaceutical Chemistry. $1^{\text {st }}$ ed. New Delhi: CBS Publishers and Distributors; 1997.p. 126-31.

27. Singleton VL, Rossi JA. Colorimetry of total phenolics with phosphomolybdic-phosphotungstic acid reagents. Am J Enol Vitic $1965 ; 16: 144-58$

28. Arvouet-Grand A, Vennat B, Pourrat A, Legret P. Standardization of propolis extract and identification of principal constituents. J Pharm Belg 1994;49:462-8.

29. Mensor LL, Menezes FS, Leitão GG, Reis AS, dos Santos TC, Coube CS, et al. Screening of Brazilian plant extracts for antioxidant activity by the use of DPPH free radical method. Phytother Res 2001;15:127-30

30. Oyaizu M. Studies on products of browning reactions: Antioxidative activities of browning reaction prepared from glucosamine. Jap J Nutr 1986;44:307-15.

31. Smirnoff N, Cumbes QJ. Hydroxyl radical scavenging activity of compatible solutes. Phytochem 1989;28:1057-60.

32. Jiang B. Extraction of water-soluble polysaccharide and the antioxidant activity from Ginkgo biloba leaves. Med Chem Res 2010;19:262-70.

33. Re R, Pellegrini N, Proteggente A, Pannala A, Yang M, Rice-Evans C, et al. Antioxidant activity applying an improved ABTS radical cation decolorization assay. Free Radic Biol Med 1999;26:1231-7.

34. Dinis TC, Maderia VM, Almeida LM. Action of phenolic derivatives (acetaminophen, salicylate, and 5-aminosalicylate) as inhibitors of membrane lipid peroxidation and as peroxyl radical scavengers. Arch Biochem Biophys 1994;315:161-9.

35. Banerjee RD, Sen SP. Antibiotic activity of pteridophytes. Econ Bot 1980;34:284-98.

36. Creasey WA. Antitumoral activity of the fern Cibotium schiedei. Nature 1969;222:1281-2.

37. Davvamani SN. Screening of Indian plants for biological activity Part I. Ind J Exp Biol 1969;6:232-47.

38. Pal SK. Antimicrobial activity of ferns. IOSR J Comput Eng 2013;12:1-3.

39. Gülçin I, Büyükokuroglu ME, Oktay M, Küfrevioglu OI. Antioxidant and analgesic activities of turpentine of Pinus nigra Arn. Subsp. Pallsiana (Lamb.) Holmboe. J Ethnopharmacol 2003;86:51-8.

40. Yen GC, Duh PD, Tsai CL. Relationship between antioxidant activity and maturity of peanut hulls. J Agric Food Chem 1993;41:67-70.

41. Tanaka T, Asai F, Iinuma M. Phenolic compounds from Peperomia obtusifolia. Phytochem 1998;49:229-32.

42. Li HY, Hao ZB, Wang XL, Huang L, Li JP. Antioxidant activities of extracts and fractions from Lysimachia foenum-graecum Hance. Bioresour Technol 2009;100:970-4.

43. Singh R, Singh S, Kumar S, Arora S. Evaluation of antioxidant potential of ethyl acetate extract/fractions of Acacia auriculiformis A. Cunn. Food Chem Toxicol 2007;45:1216-23.

44. Yua JO, Liao ZX, Lei JC, Hu XM. Antioxidant and cytotoxic activities of various fractions of ethanol extract of Dianthus superbus. Food Chem 2007; 104:1215-9.

45. Gursoy N, Sarikurkcu C, Cengiz M, Solak MH. Antioxidant activities, metal contents, total phenolics and flavonoids of seven Morchella species. Food Chem Toxicol 2009;47:2381-8

46. Mau JL, Chang CN, Huang SJ, Chaen CC. Antioxidant properties of methanolic extracts from Grifola frondosa, Morchella esculenta and Termitomyces albuminosus mycelia. Food Chem 2004;87:111-8.

47. Valko M, Leibfritz D, Moncol J, Cronin MT, Mazur M, Telser J, et al. Free radicals and antioxidants in normal physiological functions and human disease. Int J Biochem Cell Biol 2007;39:44-84.

48. Ye CL, Huang Q. Extraction of polysaccharides from herbal Scutellaria barbata D. Don (Ban-zhi-lian) and their antioxidant activity. Carbohydr Polym 2012;89:1131-7.

49. Liu W, Wang H, Pang X, Yao W, Gao X. Characterization and antioxidant activity of two low-molecular-weight polysaccharides purified from the fruiting bodies of Ganoderma lucidum. Int J Biol Macromol 2010;46:451-7.

50. Cai Y, Luo Q, Sun M, Corke H. Antioxidant activity and phenolic compounds of 112 traditional Chinese medicinal plants associated with anticancer. Life Sci 2004;74:2157-84.

51. Elmastaş M, Turkekul I, Oztürk L, Gülçin I, Isildak O, Aboul-Enein HY, et al. Antioxidant activity of two wild edible mushrooms (Morchella vulgaris and Morchella esculenta) from North Turkey. Comb Chem High Throughput Screen 2006;9:443-8. 